\title{
NORTHERN MOCKINGBIRD AND SWAMP SPARROW OVERWINTER IN CALGARY
}

\section{ROSS D. DICKSON, \#5-2303 22 Street Northwest, Calgary, Alberta. T2M 3W5}

Throughout the winter of 1990-91, Calgary birdwatchers had an opportunity to monitor the behaviour of two species rarely reported in the city.

During a long cold spell in late December 1990, an adult Northern Mockingbird was first reported feeding on peanuts at a bird feeding station in the Glamorgan subdivision. The daily mean temperature for the period from 18 December to 10 January was $-19^{\circ} \mathrm{C}$ with daily minimums colder than $-30^{\circ} \mathrm{C}$ on six days. ${ }^{2}$ For the remainder of the winter, temperatures were generally above the long-term average with near normal snowfall.

Northern Mockingbirds are wellknown for aggressive territorial defence of winter feeding areas, especially against other fruit-eating birds. ${ }^{3}$ On sunny days the Calgary bird often sat in a lilac shrub beside the south-facing side of a house, loudly calling "chick-chickchick," which is a form of territorial behaviour. ' The mockingbird became relatively inactive when temperatures dropped, perching with fluffed up feathers. Only seed-eating birds such as Pine Grosbeak and Common Redpoll were seen in the area, despite a record high number of Bohemian Waxwings in the city. The territory, which encompassed about five house lots and two feeding locations, also featured a few fruit-bearing shrubs and Mountain ash (Sorbus spp.). Orientation of the houses and trees reduced the effects of northerly and westerly winds.
A common winter problem of the Mimidae family is cold feet and legs. On cold days, this mockingbird tucked its left leg into its belly feathers whenever it perched. During the 1988-89 winter, a Brown Thrasher with cold feet - it walked with difficulty - learned to sit in the radiated heat from a lightbulb within a large bird feeder near Turner Valley, Alberta (Tom Webb, pers. comm.).

The winter range of the Northem Mockingbird is the southern U.S. and Mexico. ${ }^{5}$ However, with increasing frequency, the species is found on some Christmas Bird Counts in eastern Canada and one was present until late January in Calgary in 1958. 4,6

A reclusive Swamp Sparrow which survived along a riverbank of the Bow River in northwest Calgary was the first Alberta wintering record. The bird showed strong site fidelity to a brushy thicket approximately $60 \mathrm{~m} \times 5 \mathrm{~m}$ in area, bordered inland by a chainlink fence around a condominium complex.

A nearby homeowner provided a com. mercial bird food mixture, but the bird had not been seen to eat the offering until a late February snowfall buried its foraging area. It had spent a considerable amount of its time scratching among leaf trash left bare after a January chinook (Russ Dickson, pers. comm.). This species is considered to be the most insectivorous of the Melospiza sparrows, with a typical winter diet consisting more of animal matter than seeds. ${ }^{1}$ 


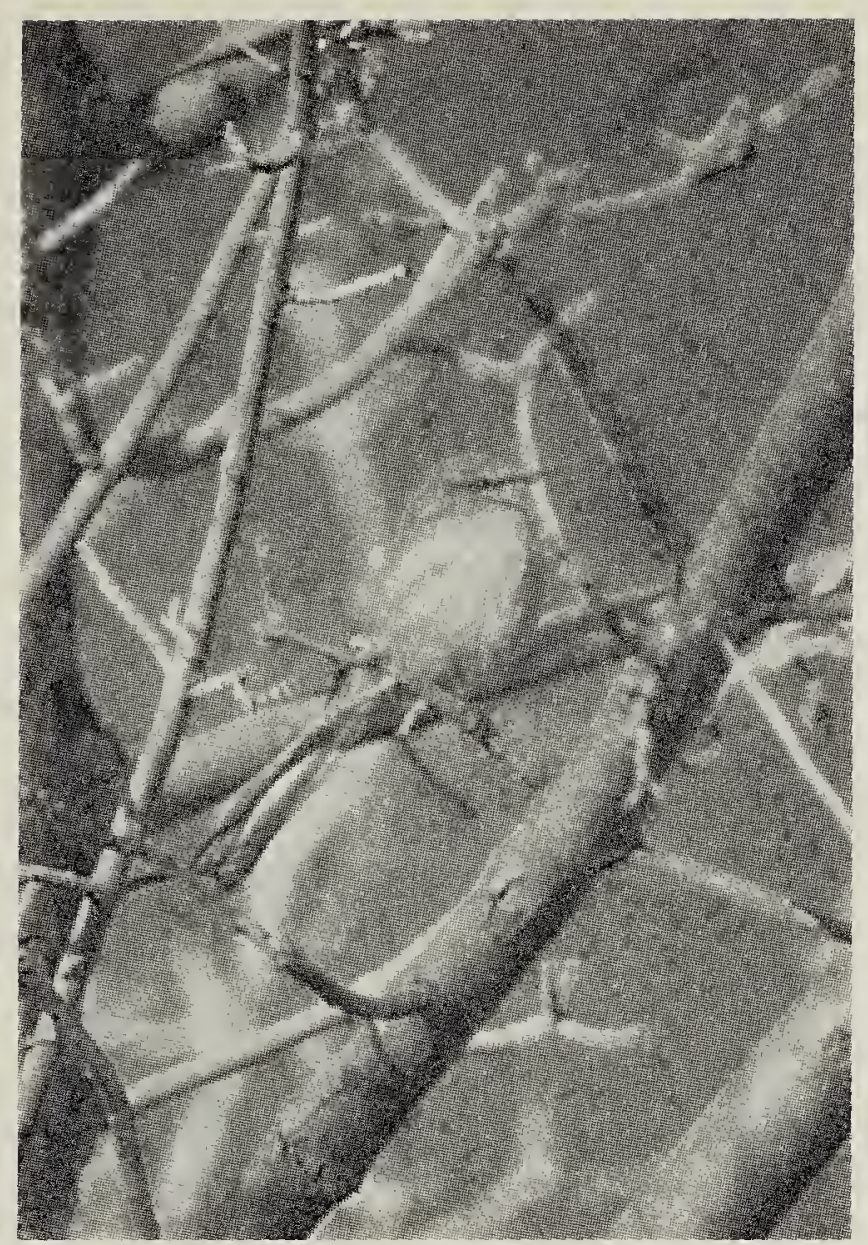

\section{Northern Mockingbird} in Calgary

Douglas Collister

Hibernating insect larvae and eggs were likely typical winter fare, although seeds were possibly also available in the thicket composed of Balsam Poplar (Populus balsamifera), Red-osier Dogwood (Cornus stolonifera), Silverberry (Elaeagnus commutata), Canada Thistle (Cirsium arvense) and some grass.

The sparrow appeared to roost overnight along the river cutbank where a tangle of overhanging roots and fallen tree branches had formed a series of tiny caves about $30 \mathrm{~cm}$ above the ice.

Three Swamp Sparrows, believed to be on migration, were recorded in the first week of October at the Inglewood Bird Sanctuary which is downstream from this site. This bird was first seen on 17 December 1990, on the Christmas Bird Count. The species is recorded on some Christmas Bird Counts in the Atlantic Provinces and at Point Pelee, but is seen much more frequently in swampy thickets in the southeastern United States. ${ }^{4,5}$

The choice of Calgary as a wintering location was unexpected in that the city is somewhat removed from the closest summer range of either bird. Northern Mockingbirds are considered to be extremely rare breeders in the southeastem part of Alberta. Swamp sparrows are locally uncommon breeders in the Rocky Mountain foothills. The availability of food combined with a relatively mild micro-climate appear to be the two main factors in the survival of these two birds.

1. BENT, A.C. 1968. Life histories of North American cardinals, grosbeaks, buntings, towhees, finches, sparrows and allies. Dover, New York. Vol. 3:1474-1490.

2. ENVIRONMENT CANADA. Climatological summaries for December, 1990 and January 1991 at Calgary International Airport.

3. LOGAN, C.A. 1987. Fluctuations in fall and winter territory size in the Northem Mockingbird. J. Field Ornithology 58:297-305.

4. NATIONAL AUDOBON SOCIETY. 1990. The 90th Christmas bird count. Am. Birds 44:547-894.

5. NATIONAL GEOGRAPHIC SOCIETY. 1987. Field guide to the birds of North America. Second edition. Natl. Geographic Soc., Washington. pp. 336, 406.

6. SALT, W.R. and J.R. SALT. 1976. Birds of Alberta. Hurtig, Edmonton. pp. 317, 470.

7. STOKES, D.W. 1979. A guide to bird behaviour. Little, Brown, and Co., Toronto. Vol. 1:187-199. 